\title{
«THE SILVER AGE OF PIRACY»: FRENCH PIRATES IN THE ATLANTIC IN THE FIRST THIRD OF THE XVI CENTURY
}

(C) 2020

\author{
Ashrafyan K.E. \\ Moscow Region State University (Moscow, Russian Federation)
}

Abstract. The purpose of the study was to find a causal relationship between the activities of king Francis I and the large-scale pirate actions of the captains of the French merchant fleet, Jean Ango. This was necessary to show piracy as a fusion of the military and diplomatic policies of France against Portugal and Spain with the naval experience of warfare on the seas and in the oceans, which had the captains of the merchant fleet of Jean Ango. We can see this connection by the captured and looted of hundreds of ships in Portugal and Spain with the full support of piracy from the French crown. The goal was also to show how France, through piracy and its promotion at the state level, destroyed the system of international agreements and Royal oaths in the Christian world for the sake of its commercial advantage. The author studies and gives examples of numerous acts of piracy, numbering in the hundreds of captured, robbed, and sunk ships, the reasons and conclusions are given why Francis I began to demand «Open seas and oceans» and why he demanded a revision of the borders of the world in the XVI century. The author has considered and found the answers to the questions of what caused the rupture of international treaties, on the part of Francis I. The author has also revealed and shown the facts of multiple penetrations of France on the territory of Portugal and Spain, which later led to attempts by France to establish settlements in Brazil in 1555-1559 and Spanish Florida in 1563-1565, contrary to all international norms and agreements - the Pope's bulls of 1493 and the Treaty of Tordesillas of 1494 and subsequent ones. The paper shows that the scale and scope of the pirate actions of French pirates in the Atlantic contributed to the formation of piracy as a mass phenomenon and can be called the «Silver age of world piracy», which falls on the $16^{\text {th }}$ century, and anticipates the "Golden age of piracy» of the $17^{\text {th }}$ and $18^{\text {th }}$ centuries. This term is quite appropriate to introduce for this time, especially if it is considered together with the even larger-scale pirate actions of Berber pirates in the Mediterranean, which are quite well known and described in the scientific literature.

Keywords: Piracy; Francis I; Jean Ango; Jean Fleury; Jean Verrazano; Jean Florin; Janus Verrazanus; Jehan Verrassenne; Jehan de Verrazane; Geovanni da Verrazano; Verrazzano; Jean le Florentino; Jean le Florentin; Jean Florin; West Indies; Charles I; treasure of Montezuma; West Indies; Brazil; Atlantic Ocean; world division; Portugal; Habsburg Empire; XVI century; trade fleet; Dieppe; Silvester Billes; Jean Terrian; pirates; Atlantic Ocean; Silver Age of Piracy.

\section{ФРАНЦУЗСКОЕ ПИРАТСТВО В АТЛАНТИКЕ В ХVI ВЕКЕ КАК ВАЖНАЯ ЧАСТЬ «СЕРЕБРЯНОГО ВЕКА ПИРАТСТВА» В МИРОВОЙ ИСТОРИИ} (C) 2020

Ашрафьян К.Э.

Московский государственный областной университет (г. Москва, Российская Федерация)

Аннотащуия. Цель исследования состояла в том, чтобы найти причинно-следственную связь между деятельностью короля Франциска I и масштабными пиратскими действиями капитанов французского торгового флота Жана Анго (Jean Ango), чтобы показать пиратство как сплав военной и дипломатической политики Франции против Португалии и Испании. Эту связь необходимо было выявить и доказать на примерах массового уничтожения сотен судов Португалии и Испании при полной поддержке пиратства со стороны французской короны. Также целью было показать, как Франция с помощью пиратства и его поощрения на государственном уровне разрушала систему международных соглашений и королевских клятв в христианском мире в угоду своей коммерческой выгоде. Исследованы и приведены примеры многочисленных пиратских актов, исчисляющихся сотнями захваченных, ограбленных и потопленных судов. Названы причины и сделаны выводы, почему Франциск I стал требовать «открытых морей и океанов» и почему он потребовал пересмотра границ мира в XVI веке. Дан ответ на вопрос, что стало причиной разрыва международных договоров со стороны Франциска I, выявлены и показаны факты множественного проникновения Франции на территории Португалии и Испании, что в дальнейшем привело к попыткам Франции создать поселения в Бразилии в 1555-1559 годах и в испанской Флориде в 1563-1565 годах вопреки всем международным нормам и соглашениям - буллам папы римского от 1493, Тордесильясскому договору 1494 года и последующим документам. В статье показано, что по своим масштабам и размаху действия французских пиратов в Атлантике способствовали становлению пиратства как массового явления. XVI век можно назвать «серебряным веком мирового пиратства», который предвосхищает «золотой век пиратства» XVII-XVIII веков. Этот термин вполне уместно ввести для указанного времени, особенно если это рассматривать вместе с еще более масштабными пиратскими действиями берберских пиратов в Средиземном море, достаточно хорошо известными и описанными в научной литературе.

Ключевые слова: пиратство; Франциск I; Жан Анго; Жан Флери; Жан Верразано; Жанус Веразанус; Жан Флорин; Вест-Индия; Карл I; Карл V; сокровища Монтесумы; Вест-Индия; Бразилия; Португалия; Габсбурги; XVI век; торговый флот; Дьепп; Сильвестр Биль; Жан Терьон; пираты; Атлантический океан; серебряный век пиратства; Тордесильясский договор; булла 1493; норманны; свобода морей и океанов. 


\section{Research materials and methods}

We used a lot of materials from the scientific works of France, the USA, the UK, Turkey, and Russia. We have studied many articles, theses, books with original documents [1] by used sources from internet-platforms and encyclopedias. There were many materials that were analyzed and compared from the point of view of our topic of the cause-and-effect relationship of king Francis I of France and the shipowner Jean Ango and the actions of his captains Jean Fleury (Jean Florin) and others.

\section{Main findings}

We have been able to show by many examples that piracy had a point of sharp acceleration since 1522, when the Aztec treasure was captured.

The profit from seized Portugal and Spain ships with goods, gold and silver was the main point that gave rise to piracy as a method of generating revenue for the French crown, which receives a share of the pirate loot for helping the pirates and "protecting» them.

The base of piracy was the merchant fleet of 70 ships of the shipowner Jean Ango and captains such as Jean Fleury and others.

We proved that King Francis I of France was the main figure who supported and developed piracy as a state policy even before Queen Elizabeth I of England.

We showed that France proclaimed the principle of the «Open Seas and Oceans» and demanded a revision of the borders because it wanted to spread illegal trade operations and wanted to found their own settlements in America to have money for the wage war in Europe (to continue the Italian war). France breached the system of agreements between European countries and this let the Piracy in the Atlantic as well as the profit of the merchant fleet of Ango grow and allowed to increase the Treasury of the King Francis I of France.

\section{Social implication of our investigation}

This study of French king Francis I actions is very relevant today when the structure of the world order is also collapsing. We are looking at a situation where France and Francis I were personally responsible for the growth of piracy in the world and the termination of agreements between European countries and the disruption of normal trade in the world. We showed that France was the first country in the world where piracy was raised to the cult of country politics and was a profitable business for the Crown of France, and this was before the English policy of Elizabeth I that used piracy to accumulate capital for England.

Social significance of the work is to turn the accepted opinion of the world scientific community to the earlier development of piracy in the waters of the Atlantic and Europe and to declare the "Silver Age of Piracy», provoked by the actions of the French king Francis I to break all treaties and agreements in Christendom. This can be seen as rewriting textbooks in all educational institutions and showing a more accurate history of the rise of piracy for teaching schoolchildren and students.

Novelty of the study

There are many scientific articles about piracy in the late sixteenth and seventeenth centuries, especially after Francis Drake in the last quarter of the sixteenth century. We have revised this question to change the opinion of the scientific community and students that the era of piracy began before the time of Elizabeth I and Francis Drake. They showed the rampant piracy on the seas and identified the «Silver age of piracy» on the vast seas and oceans, which preceded the "Golden Age». We have shown that growing piracy became a threat to the entire world due to the merging of commercial interests in making a profit by any means for the merchant fleet of Jean Ango's ownership and the need to replenish the Treasury of France by King Francis I.

The object of the study was the pirate activity in the world history, which came from the French merchant fleet led by Jean Ango's ownership and by the support of king Francis I of France, which was recorded by Portugal and Spain, as well as the claims of France to change the borders of the world.

The subject of the study was the period from 1504 to 1528. We were guided by the translation of original documents and letters, as well as books, articles, researches, etc., which confirmed the pirate campaigns of the captains of Jean Ango's Trade Fleet with the consent and direction of king Francis I of France, which caused a surge in the spread of piracy in the Atlantic Ocean and other areas of the world ocean and had harmful consequences for the world history.

\section{The main part}

There is a Papal Bull of 4 May 1493 [2, c. 486-489] and the Treaty of Tordesillas of 1494 [3] about the division of the whole world into two parts between the Christian countries - Portugal and Spain.

Although France did not participate in the division of the world in 1494, but the French reached Guinea (Africa) before Portugal and even had trading rows in the markets there in 1364 [4, p. 6-7].

In the North of France, in Dieppe in the late $15^{\text {th }}$ early $16^{\text {th }}$ centuries, a large merchant fleet of Normans was based. This merchant fleet was formed by Jean Ango (father), a hereditary Scandinavian from Rouen [5, p. 2], whose family moved to Dieppe in the $15^{\text {th }}$ century $[4$, p. 6]. The Normans were very good seamen throughout history and already in the early 1500 s made expeditions to distant countries. This fleet was founded by Johan Ango who was the father of Jean Ango (or Johan, or Jehan Ango) [4, p. 6] who was invited to the trade society of Dieppe in 1463 [4, p. 6; 5, p. 2] and after that the Norman fleet grew very quickly. The merchant fleet was necessary for import and export operations and Jean Ango became a great merchant and explorer. The younger Jean Ango was born in 1480 [4, p. 6] and was the son of the older Johan Ango [4, p. 10]. Jean Ango received the merchant fleet from his father and continued the business of Maritime trade with his father's friends and captains. Very often the name Jean Ango was written as Johan Ango and vice versa $[5$, p. $1-3 ; 6 ; 7]$ and it is very difficult to determine today whether the events relate to the father or to the son.

The French ships were lighter. But the French almost always caught up with the Spanish and Portuguese ships, it was not because they were better [8], but because they were empty: without cargo, unlike the heavily laden vessels that were sailing from the New World to Spain and Portugal. Almost all the ships of the Ango merchant fleet had guns for defense and very well-coordinated teams of 
experienced sailors, experienced captains and good maps of the routes of the Spanish fleet, the Portuguese fleet and the French navigators. Many merchants and traders from different countries rented these ships from the owner Jean Ango and sailed on routes to Brazil, the Spanish West Indies, Africa, etc. under different flags, but always with the crew and captains of Ango.

We can give some names of the captains of the Ango's family trade fleet: Gamart, de Rouen; Jean Denys, de Honfleur; Thomas Aubert de Dieppe, they were joined by their lieutenants Pierre Crignon, Jean et Raoul Parmentier, Pierre Mauclerc, Cardin Dulot, Richard Héron, Christophe de Prix, Mathieu Doublet, Bourry, Morel, Zanobis de Rouselay, Belleville, Silvestre Billes, etc. $[4$, p. 6].

The older Johan Ango and his son Jean Ango with their captains knew the Portuguese and Spanish fleets very well; they also knew all places and ports of Portugal and Spain in the New World. Ango's family and the captains of his fleet understood that the illegal trade brought much more money than the legal one, and they understood that the illegal trade could be conducted directly from the territories of Portugal and Spain in America. And Portuguese Brazil was the first target along the way.

There were several French ships fixed in the inland river's territory of Brazil in 1504. It was the Paraguaçu River between the modern city of Rio de Janeiro and the modern city of San Paolo [9, p. 86]. Portugal seized all French ships and punished French teams and captains because it was the territories of Portugal by the Treaty of Tordesillas of 1494. These were the ships of the trade fleet of the older Johan Ango.

In 1510 the younger Jean Ango gained the fleet of his father Johan Ango and was received as Vicont by De Boutelles and his recipient in Dieppe [4, p. 9]. There were 70 ships.

1515. Francis I received the crown of France and entered Genoa and Milan because he won the armies of Venice, the Pope of Rome and Maximilian I who was the Holy Roman Emperor. He understood the meaning of the trade by sea as a source of wealth when he saw the fleet of Venice, Genoa. After this king Francis I decided to connect his own effort with the trade fleet in France. Jean Ango was the largest and strongest ownership of 70 best trade ships [5, p. 3]. Several times king Francis I gave him his own ships to participate in the trade war against England, Portugal, and Spain [4; 5, p. 24].

1516. The Frenchmen made more activities to visit Brazil and more often visited these places. The king of Portugal complained about the French ships but soon he understood that this was the policy of France. And then the Portugal Crown sent to Brazil a revenge expedition under the head of the best captain who was Christovam Jacques [10, p. 7]. The Portuguese sank all the ships and destroyed all the settlements of France and drove the French out of Brazil [10, p. 7].

1516. The heir to a large merchant fleet, Jean Ango, sent a retribution expedition to Brazil from several ships of his fleet. The head of this expedition was Jean Fleury $[10$, p. $7 ; 11]$. He was the captain of the one from many ships of Jean Ango's ownership and his private France Trade Fleet. Jean Fleury had visited Brazil many times earlier and knew routs of Portugal ships through the Azores. So, he seized many Portugal ships in this place.
The piracy as the Second Front during the war

of Francis against the Charles V of Habsburg

1518-1519. In 1518, Maximilian I, who was Holy Roman Emperor, wrote a hidden will in favor of inheriting the crown of the Holy Roman Emperor to his grandson Charles I [12]. Charles I was the son of Philip I the Handsome [13, p. 118], the founder of the Habsburg dynasty in Spain, who was the son of Maximilian I and Joan the Mad [13, p. 605; 14], who was the queen of Castile and Aragon, the daughter of the "Catholic Kings» of Spain. Therefore, in 1519, after the death of Maximilian I, the young 18-year-old Charles I inherited the crown of the Holy Roman Empire and before it he had inherited the crown of the kings of Spain. Thus, Maximilian I took revenge on the king of France and Francis I for his defeat in the war in Europe.

1519. After Maximilian's death, all the German principalities elected Charles I as Holy Roman Emperor [15] under the name of Charles V $[13 ; 15]$. This was a severe defeat for King Francis I of France. The present territory of France was surrounded by the Habsburg Empire. This was the failure of all French victories in the wars in $\mathrm{Eu}-$ rope $[12 ; 13]$.

So in 1521 the New Italy war began between the Habsburg Empire and Francis I in the north and in the Pyrenees [16, p. 37]. The ships from the trade fleet of Jean Ango took part in attacks to Spanish galleons in the route from America. The main idea was to interrupt routes in the cargo of gold and silver which Spanish galleons reached from the New World to Spain [17].

Emperor Charles V of Habsburg needed money to cover the large expenses for the war in Europe, and he received money from the New World. In addition, king Francis I, as king of France, needed to find money to send to the war against Charles V. And Francis I founded this solution through increased Piracy activity. And it was up to Jean Ango and his captains from the merchant Navy because they were the only ones who knew the routes best and had combat experience fighting Spain and Portugal on the water expanses. 70 ships with experienced sailors and experienced captains were ready and waiting for the signal of Jean Ango [4], who was waiting for the permission of the king of France.

1521. We can learn from the documents about the mass attacks on the ships that the merchant trader Diaz Fernandez from Lisbon wrote a complaint and presented that Jehan Fleury (Jean Fleury) and his son, and Sylvester Billes robbed his ships in the port of Safo. Fernandez wrote that they were captains of the trade fleet of Jean Ango [10, p. 8].

1521. Jean Fleury captured the Spanish ship which tried to come to Bach from Hispaniola with 80000 ducats and 600 ounces of pearls and sugar.

At the end of 1521, Jean Fleury captured the Spanish ship from Hispaniola with the cargo of pearls, gold, silver, sugar and other commodities [10, p. 18].

\section{The beginning point of a sharp increase}

in piracy as the most profitable business.

The connection between the French crown and Piracy

1522. The treasure of Montezuma, who was the king of the Aztec Empire, was captured by the Frenchmen in 1522. It was the most famous moment in history. Jean Fleury, who was one of the captains of the merchant fleet of Jean Ango, managed to capture two of the three 
ships that carried the treasure of the murdered king of Montezuma, which Hernando Cortez sent from the land of New Spain (modern Mexico) to Spain. After this moment, Jean Fleury took a special place of honor among the pirates, and this moment became the starting point for the crazy growth of piracy in the world.

The famous conquistador Hernando Cortez captured the great wealth in the Aztec Empire [10, p. 15]. The Imperator Charles V Habsburg received without any excesses the first part of this wealth in the form of coins, art objects, etc. The description of these items was made in Madrid and made a strong impression [10, p. 16]. After that, Hernando Cortez prepared the next shipment of the Aztec Empire's riches for passage to Spain.

The price of all the treasures was about 200000 ducats, and Cortes sent them to Spain in three large Galleons [10, p. 18]. Cortes's friends Avilla and Hinon [18, p. 651-665] volunteered to take the treasure to Spain. Thanks to foreign sailors in the Spanish Navy and spies in the Spanish government, news of the future treasure expedition spread very quickly and became known in other countries and, of course, in France itself long before the expedition itself, back in November 1521.

On December 20, 1522. A small fleet consisting of three galleons sailed from La Vera Cruz and reached the Azores without any problems.

Jean Fleury and the owner of the trade fleet of Jean Ango knew about the departure of the ships under the head of Avilla and Hinon who were Hernando Cortes's friends. They knew that the treasure was loaded on these ships because this expedition had a great resonance in the society of the West Indies and in Spain. The pirate captain and Frenchman Jean Fleury decided to wait for the treasure convoy near Azores $[10$, p. 19; 16].

Two of three ships with Montezuma's treasure were captured by the fleet of the French. The wealth consisted of coins, art objects, etc. [10, p. 15; 16].

1522. When Jean Fleury was returning to France with Aztec treasures, he met another Spanish ship that was returning to Spain from Hispaniola (West India) with 20 000 pesos in gold, pearls, hides, and other goods. Fleury seized this ship without any serious fight $[10$, p. $21 ; 16]$.

1522. Jean Fleury returned to France to show the captured treasures to Jean Ango and to make rich gifts to Francis I and the Admiral of France [10, p. 21].

The Montezuma's treasure was shown to the shipowner Jean Ango and to king Francis I of France. The King of France was seized with envy at the treasures presented to him by Jean Fleury and Jean Ango [10, p. 21].

So, Francis I realized that he could cover the large costs of the war in Europe against the Habsburg Empire by piracy, while simultaneously depriving the Habsburg Empire of the same profit.

King Francis had a feeling of hatred for Spain. So, piracy was the perfect way to destroy any formal treaties and agreements. He realized that this was only a small part of the treasure that could be taken from the New World if French colonies of settlers were located there. The shipowner Jean Ango understood that piracy was much more profitable than regular and usual official trade. Therefore, the king of France and the proprietor Jean Ango had only one goal - to quickly increase capital and coordinate the actions of the French crown against the Spanish and Portuguese with the piratical actions of the French. When capturing Portuguese and
Spanish ships, in addition to goods, the Frenchmen captains captured maps with all routes of ships of the Spanish and Portuguese fleets.

Thus, we see that the understanding that piracy as a business can generate more profit than ordinary trading operations was the main idea of connecting the power of the French crown and the private pirate fleet consisting of the ships of Jean Ango's trade fleet. This alliance should have brought a large cash flow from gold, silver and other riches obtained through piracy and encouraged and covered by king Francis I of France.

Immediately after the successful capture of his possessions, Jean Ango sent numerous of his ships to the Azores and sent many ships to West India for the purpose of raiding Spanish ships and lands [19, p. 10].

We claim that this moment was a point of the rapid expansion of piracy, because news of the captured treasure became known in all countries of Europe. English and other sailors saw that there was a great change in a profitable business as piracy against Portugal and Spain.

\section{The demand «Freedom of Oceans and Seas»} by France

Francis I sent a request to the Imperator Charles V of Habsburg and the king of Portugal. This demand consisted of the idea of dividing the world in accordance with the interests of France. King Francis I of France declared that he refused to recognize the Treaty of Tordesillas of 1494 and other agreements and demanded «Freedom of the seas and Oceans». Francis I sarcastically said that Imperator Charles V of Habsburg and the king John III (João III) of Portugal should show him a paper from ancestor Adam, who gave them such a paper that they were the heirs of lands and oceans $[10$, p. 8-9; 17 , p. $21 ; 20$, p. 38-39]

By this action, king Francis I renounced all agreements and destroyed the system of international treaties and agreements between the Christian countries. He supported the collapse of normal trade and helped piracy grow as quickly as possible as a phenomenon. In modern terms, he declared anarchism the main principle in French policy on the international stage, gave privileges to pirates and piracy, receiving a percentage of the profits from captured ships and treasures.

We can say that the year 1522 and the capture of the Aztec king's treasure by the pirate Jean Fleury became a major moment in the world history of piracy and led to the death of the Treaty system and contributed to a very rapid growth of piracy on the seas and oceans [17]. We see that England and the Netherlands followed France on the road of piracy already prepared. Piracy as an activity brought a high percentage of profits more than any trade.

Piracy was a good way for France and as a second real front against Spain during the Italian Wars. So a new world without any rules on the seas and oceans was created by the king of France in 1522 .

Jean Fleury and other captains of the merchant fleet of Jean Ango began to loot and seize all the ships at sea. The Ango fleet consisted of many ships that, as part of entire armadas and separately attacked galleons, galleys, and other ships from Spain and Portugal all the way from the Mediterranean to the territory of modern America.

In 1522, Jean Ango's piracy continued, and he captured seven Spanish ships near Canary Islands that had been sent from Cadiz [10, p. 18]. 
1523-1524 Jean Fleury, Belleville and Silvester Billes created a large pirate fleet of ships belonging to Jean Ango and other French Normans. He attacked all Portuguese and Spanish ships from Brazil and the West Indies and near the coast of Portugal. Pirates seized all the cargos under threat of sinking. Jean Fleury sank all ships if anyone resisted his pirate attack.

It was a rematch for France's defeat in Brazil [10, p. 13].

1523, June. Trader Giorgio Nunes submitted documents that showed that 7 ships from France had robbed his ships on the orders of Jean Fleury, Belleville and Sylvester Bille and the owner of this ship was Jean Ango $[7$, p. 8].

1523. French pirate, Jean Fleury, captured a Portuguese ship that was returning from India with a cargo of 18000 Portuguese reals [10, p. 10-11].

Francis I wanted to find any way to take 'part of the pie' that was called America and tried to find any possible way to declare new lands in America territories of France. 1523 the Portuguese Ambassador to France sent two letters to the king of Portugal on March 27 and April 25, 1523, about Verrazano [21, p. 141] (or Jean le Florentin, or Jean Verazzano) that Juan Verrazano, who was born and lived in Florence, offered to serve king Francis I of France to open the Eastern lands to France, and he stated that Portugal had not seen these lands. In addition, the Ambassador wrote that there were several fleets of ships in Normandy that were preparing to occupy the lands of Brazil. This letter disrupted Verrazano's plan to find land near Brazil, and he changed course to North America [10, p. 9-10].

Interesting, that in the end Frenchmen founded the settlements in Brazil in 1555 [22, p. 112-113].

We can confirm that Verrazano was a pirate. There was a real document that the owner Jean Ango agreed to provide four ships for Verrazano by the order of king Francis I of France. But he demanded that Jean Verrazano fulfill his condition. Jean Ango demanded that Verrazano capture the Spanish ships and escort them to the city of Dieppe [4, p. 14] with goods, as well as pay for the lease of 4 ships for his expedition to America. So, Verrazano complied with this request, and captured and escorted the Spanish ships to Dieppe. Therefore, he took part in piracy against Spain. Verrazano lost two of Jean Ango's ships during a storm. And this fact explains why he had two ships during the expedition to America instead of the requested four ships.

\section{Francis I received the right to request}

to review the division of the World

An important factor was that the Pope Clemens PP. VII (Florentine Giulio de Medici) sided with France in 1524. This spurred king Francis I to quickly send Verrazzano to open up new lands so that claims could be made for the division of the world while the Pope was on his side.

On 17 January 1524 Jean Verrazano (Janus Verrazanus or Jehan Verrassenne or Jehan de Verrazane or Geovanni da Verrazano or Verrazzano or Jean le Florentino or Jean le Florentin or Jean Florin) [21, p. 4] sailed by two ships «La Dauphine» and «La Normande» which had Jean Ango's ownership [4; 21, p. 170; 22] under the flag of France to the New World [20, p. 39-40]. Only
«La Dauphine» reached the Cape Fear and sailed to the north to Newfoundland.

On 8 July 1524 Verazzano returned to Dieppe and presented a map (but it was a wrong map $[20 ; 23 ; 24$, p. 41-42] and this expedition gave the reason to request from the Pope of Rome to review the division of the World with the interest of France.

The voyage of Verrazano was the main reason to demand Francis I take all territories from Cape Fear to Newfoundland.

\section{The next step of growing of Piracy}

by the ownership of Jean Ango

1524, March. The Fleet of 5 ships of Jean Ango under the head of captain Solvester Billes (or Silvestre or Sylvester or Silvester) from Dieppe seized Spanish ships near Canaries Island which sailed to Sevilla.

1524. Jean Fleury and Jean Terrian sent the next fleet of 8 ships against the Spanish and Portugal and captured 30 Portugal and Spanish ships.

1524. The fleet of 5 French ships under the head of captains Jean Fleury and Sylvester Billes from Jean Ango's ownership seized several Portugal ships near Viana and one more Portugal ship was captured near the Cape St. Vincent (Cabo de São Vicente) near the coast of Portugal.

On 6 September 1524 one more Portugal ship was captured [10, p. 11].

3 October 1524 . The fleet of Jean Fleury attacked a Portugal ship again near the Cape of St. Vincent near Portugal. The ships of pirates had Jean Ango, Bellville and Ferei's ownerships.

October 1524. This fleet attacked Portugal, sank the ships and killed the people.

1525. Ango had ships in Newfoundland, in the West Indies, in Brazil, near the coast of Africa, and he was preparing to travel to the East Indies. Georges D'amboise presented him at court. And Jean Ango became immensely rich [4, p. 16].

Spring 1525. 3 ships of Portugal were robbed in the Atlantic near Tenerife and near Portugal coast [9].

In 1525 Silvestre Billes ou Billas seized 3 Spanish ships and then he sold them all [10, p. 22].

1526. The same fleet of Jean Ango's ownership continued to rob and sink the ships of Portugal and Spain on the same route.

The new war in Europe against Spain

In 1525, king Francis was captured after the battle of Pavia and was forced to sign the peace in Madrid, but as soon as he was released, he immediately broke his Royal word and began to unleash military actions against Charles V, establishing contacts with the enemy of the Christian world - the Ottoman Empire against Charles V $[15$, p. $35 ; 25]$.

On 22 May 1526 the king of Francis I founded the anti-Habsburg coalition (alliance) which was named the League of Cognac and which consisted of France and Pope, Venice, Florence, England, and Genoa.

1527. Jean Fleury attacked and seized Portugal ships near the route between Spain and Portugal. The pirate fleet consisted of 2 and later 4 and later 5 French ships.

1527. Later Jean Fleury waged war in the English Channel to seize Portuguese ships that usually used this route to return from far trips of trade [10, p. 14].

1527. Jean Fleury captured ships near Flanders. 
The punishment of pirates

September 1527. Four ships of the Spanish fleet surrounded and captured Jean Fleury while he was with 130 Frenchmen. About 80 Frenchmen were killed. He was captured and taken to Cadiz, from there he was sent to Madrid, and then Jean Fleury was transferred to Colmenar de Arenas, near Toledo (Spain) [7, p. 4].

On 3 October 1527, Jean Fleury was sentenced to be hanged by Charles V of Habsburg and was hanged [17] in November in the port Pico (Spain). His friends and pirates La Salle, Losbard, Lando Lane, Vispar et Faran were hanged altogether with him. Limousin, Jean de Mensieris and others were sent to galley as slaves [10, p. 22].

1528. French pirate ships from the fleet belonging to Jean Ango took revenge and burned the city of San German in Puerto Rico in the West Indies [17], which was Spanish territory in the West Indies [6].

In 1530. The dominions of Jean Ango threatened Spain and demanded the release of all French pirates, not only for the officers, but also for the sailors (Jehan Bon, Michiel de Strichiau, Guillot Anise, Robert Heliot, Robin le Boyde, Nicolas le Gascon, Robin Sanson) [10, p. 25].

The new age in Piracy was established in 1530 by a connection between king Francis I and the pirate's fleet of Jean Ango when King Francis I of France gave the «mark» as permission to rob and capture Portugal. The pirate leader and owner, Jean Ango, believed in himself and blockaded Portugal with his fleet in 1530. During the blockade, the Portuguese saw Jean Ango and sent a request to the French king for his illegal support of Jean Ango. King Francis I of France uttered a very historical phrase: «This is his business, not mine!» $[10 ; 19$, p. 10 11; 23]. Francis made piracy an important state policy, encouraging this type of activity on the part of the crown. He encouraged piracy and gave his Royal assent to the actions of the Ango fleet, on the one hand, and said that it was «not his business» to stop pirates, on the other hand.

It's an interesting fact that after the death of king Francis, Jean Ango fell victim to rivals and in 1549 was imprisoned on charges of official crimes [10].

\section{Testimonies about atrocities of the Frenchmen}

There was no mercy and pardon during the piracy raids. Some testimonies described how the French enjoyed watching the torment. Once they buried prisoners up to their shoulders and used their heads as targets, then brought the bodies of their enemies as food for cannibal tribes, and they burned the bodies at the stake and ate them [7, p. 19]. It suggests that people who embark on the path of piracy lose their human appearance and become psychologically different people-officers and captains of the regular army, even at that time, would not have treated prisoners in this way.

\section{The result of the piratical activity}

of the French merchant fleet owner Jean Ango

and his support by king Francis I of France

The existing of the piracy fleet of Jean Ango's ownership near Portugal water was fixed by evidence in documents from 1521 to 1527 . This evidence is not doubtful [10, p. 15].
More than 200 ships were robbed and seized by Frenchmen of Jean Ango and by the support of the French Crown between 1551 and 1559, but actually there were much more ships because many ships were sunk with teams and passengers $[6 ; 7 ; 11 ; 17 ; 19 ; 26]$.

1531. The king of Portugal Juan III sent to the Ambassador of France in Portugal documents with the words that vassals of the king of France captured more than 300 ships of Portugal [4, p. 6; 10, p. 18]. The piracy were robbing peaceful traders for millions of cruzados (Portugal's coins); there were a lot of examples of violence, kidnappings, many months of prisons for people, etc by the captains of Jean Ango's fleet and Frenchmen sailors-pirates. The king of Portugal said that this treatment of people took place softer even during the war against Muslims [10, p. 6].

Jean Fleury with his friends and sailors captured many of Portugal and Spanish ships, robbed and killed ships' teams. Spain was especially afraid of Jean Ango's ships after they captured the treasure of the king of Aztecs in 1522 . The historians of the $16^{\text {th }}$ century wrote many documents about the crimes of Jean Ango's ownership and his captains.

\section{Conclusion}

We believe that we managed to show by many examples in our paper that piracy had a point of sharp acceleration since 1522 (you can find a description of Montezuma's treasures here [10, p. 16]). The moment when the Aztec's treasure was captured was an important moment in the history of the piracy, because the wealth was shown to king Francis I, and he realized that the treasures were hidden in the New World.

We also showed that the development of piracy was a desire for quick profits and allowed us to establish a mutual interest between the merchant fleet of the shipowner Jean Ango and the ambitions of king Francis I of France. It was the desire to master America and profit from it to conduct their wars that drove the king of France. This can explain his desire to change the rules and existing borders of the Christian world and the world trade. This was the main point that gave rise to piracy as a method of generating revenue for the French crown, which receives a share of the pirate loot for helping the pirates and «protecting» them. All international rules and all international agreements were violated by Francis I, and had only one goal - the rapid enrichment of the Treasury to continue the wars in Europe. Piracy has shown that from an economic point of view it generates more profit than trade or war in the new territories with the natives. France provided Dieppe and the seaports as territories where pirates felt safe under the protection of the French state. And for security and impunity, the pirates were willing to pay for mutual pleasure.

King Francis of France has chosen a position of genius: he encouraged piracy but said it was not his province or business, but that of a private merchant. Francis I lied because he had a large profit from every ship captured, and he had a free and powerful second front against the enemy without any payment for the soldiers. From encouraging piracy, he had the money for the war in Europe (the Italian war). To make a profit, he did not need to fight with the natives or build mines to extract gold or silver in America, but only to shelter and encourage murderers and rapists-pirates. King Francis I showed 
his real attitude and support every time for pirates when he gave the «mark» as permission to rob and capture Portugal ships.

We have shown that the personal hatred of Francis I for Charles $\mathrm{V}$ is connected with the loss of the crown of the Holy Roman Emperor by Francis in 1519. He was forced to sign the embarrassing Treaty of Madrid in 1526 after being captured at the battle of Pavia in 1525 .

Attempts to open up new lands were a plan to legitimize the French presence in the Atlantic Ocean and establish a new world order in favor of France. French pirates and Barbary corsairs (or Ottoman corsairs) were the main force in the destruction of the old order of the Treaty system, which destroyed any contractual obligations between Christian countries and which was directed against the Iberian monarchs of Portugal and Spain and the other European States in favor of the economic interests of Francis I of France.

On the conscience of the French pirates of the merchant fleet of the shipowner Jean Ango are the lives of civilians, burned cities and settlements in the West Indies, New Spain or Brazil, the capture of merchant ships, murders and kidnappings, etc. Transmitting information about the routes of Christian ships for the pirates and the fleet of the Ottoman Empire $[6 ; 15]$. And we state that king Francis I was the main figure who supported and developed piracy as a state policy even before Queen Elizabeth I of England. And the main accomplice to piracy was the merchant fleet of 70 ships of the shipowner Jean Ango and captains such as Jean Fleury and others. Even the expedition of Jean Verrazano to America had a very transparent purpose of searching for any territory as a reason to revise and change the world to the benefit of Francis I, and France did this by piratical methods.

We would like to consider this issue in order to change the opinion of the scientific community and students that the Age of piracy began at the time of Elizabeth I and Francis Drake. We would like to show the «Silver Age» of piracy on the vast seas and oceans, preceding the «Golden Age» $[19 ; 23 ; 27 ; 28 ; 29]$. They also wanted to point out that the growing piracy as a public and commercial threat to the world was made by France and personally by king Francis I and Jean Ango [4; 5], who was the owner of a huge French merchant fleet consisting of 70 ships, as well as its captains. Thus, we wanted to introduce a new term "Silver age of Piracy» foreshadowing the "Golden Age of Piracy» of the $17^{\text {th }}$ $18^{\text {th }}$ centuries which has been described very well $[9 ; 15$; $23 ; 25 ; 29]$, and lay the blame for the rapid growth of piracy and the destruction of international agreements on the French king Francis I. Demands for freedom of the seas and oceans and attempts by the French to establish themselves in Portuguese Brazil in 1555-1559 and in Spanish Florida in 1563-1565 [1;22; 30; 31] and rewrite the ownership of these lands in their favor were the result of the policy of Francis I in the $16^{\text {th }}$ century - the century of the «Silver Age of Piracy» and lawlessness on the seas and oceans.

\section{References and bibliography:}

1. Basanier M. L'histoire notable de la Floride située es Indes Occidentales, contenant les trois voyages faits en icelle par certains capitaines \& pilotes françois, descrits par le capitaine Laudonnière, qui y a commandé l'espace d'un an trois moys: à laquelle a esté adiousté un quatriesme voyage fait par le capitaine Gourgues, chez Guillaume Auuray. Paris: Chez Guillaume Auuray, 1586. 126 p.

2. Хроники открытия Америки. Новая Испания. Кн. I: Исторические документы. Изд. 1-е. М.: Академический проект, 2000. $496 \mathrm{c}$.

3. Tratatos de Tordesillas I-II [Internet] // Gobierno de Espania. Ministerio de Educacion y Educion Profesional. https://sede.educacion.gob.es/publiventa/PdfServlet?pdf=V P01169.pdf\&area=E.

4. Gravier G. Jean Ango: Viconte de Dieppe. Rouen. A. Lestringant, 1903. 38 p.

5. Guenin E. Ango et ses pilotes d'apres des documents inedits tires des archives de France, de Portugal et D'Espagne. Paris: Paris Imprimerie Nationale, 1901. 314 p.

6. Rogozinski J. Pirates! Brigands, Buccaneers, and Privateers in Fact, Fiction, and Legend. New York: First American Edition, 1995. 416 p.

7. Buti G., Hrodej P. Histoire des pirates et des corsaires. De l'antiqu: De l'Antiquité à nos jours. French Edition. Edición Kindle.-e. Paris: CNRS, 2016. 608 p.

8. Holmes G.V. Ancient and modern ships. Part I. Wooden sailing-ships. London: Wyman and Sons, Limited, Fetter Lane, E.C., 1906.

9. Boxer C.R. The Portuguese seaborne empire: 14151825. London: Hutchinson, 1969. 426 p.

10. Gaffarel P. Le Corsaire Jean Fleury. Leon: Imprimerie E. Cagniard, 1902. 26 p.

11. Craven C.K. The sixth-most successful pirate of the Golden Age: Jean Fleury [Internet] // The Richmond Observer. - https://www.richmondobserver.com/lifestyle/item/ 3361-the-sixth-most-successful-pirate-of-the11-golden-agejohn-fleury-32-million.html.

12. Kann R.A. A history of the Habsburg Empire, 1526-1918. Los Angeles: University of California Press, 1980. 664 p.

13. Prescott W.H. The History of the Reign of Ferdinand and Isabella the Catholic. London: Samuel Bentley, 1883. Vol. 3. 616 p.

14. Prescott W.H. The history of the Reign of Ferdinand and Isabella the Catholic. Cambridge: George Routledge, 1854. Vol. 1. 412 p.

15. Gürkan E.S. Ottoman corsairs in the Western Mediterranean and their place in the Ottoman-Habsburg Rivalry (1505-1535). Ankara, 2006. 179 p.

16. Guizot F.P. A popular history of France from the earliest times by Francois Pierre Guillaume Guizot. New York: John B. Alden, Publisher, 1885. Vol. IV. 448 p.

17. Salas R.S. Los piratas franceses en América: la respuesta española en el siglo XVI [Internet] // Credencial Historia. 1997. № 89. - https://www.banrepcultural.org/ biblioteca-virtual/credencial-historia/numero-89/los-piratasfranceses-en-america.

18. Дель Кастильо Б.Д. Правдивая история завоевания Новой Испании. М.: Форум, 2000. 678 с.

19. Rediker M.V. Atlantic Pirates in the Golden Age. Boston: Beacon Press, 2004. 248 p.

20. Копелев Д.Н. Раздел океана в XVI-XVIII веках: истоки и эволюция пиратства. СПб.: Крига, 2013. 734 с.

21. Murphy H.C. The Voyage of Verrazzano: a chapter in the Early History of Maritime Discovery in America. New York: Press of Munsell, 1875. 198 p.

22. Merás G.S. Pedro Menéndez de Avilés and the conquest of Florida: a new manuscript. Gainesville: University Press of Florida, 2017. 431 p.

23. Unger R.W. Dutch nautical sciences in the Golden Age: the Portuguese influence // e-Journal of Portuguese History. 2011. Vol. 9, № 2. P. 68-83. 
24. Маховский Я. История морского пиратства / пер. с польск. М.: Наука, 1972. 288 с.

25. Prescott W.H. History of the Reign of Ferdinand and Isabella the Catholic. Honolulu: University Press of the Pacific, 2003. $724 \mathrm{p}$

26. Johnson Ch. A general history of the pyrates / ed. by Manuel Schonhorn. Columbia, SC: The University of South Carolina Press, 1972. 800 p.

27. Томас X. Золотой век Испанской империи. М. Издательство АСТ, 2010. 930 c.

28. Паутов Д.А. Пиратская республика на Багамских островах: причины возникновения и влияние на систе- му управления островами // Самарский научный вестник. 2020. Т. 9, № 1 (30). С. 164-168.

29. Calendar of state papers colonial, America and West Indies // ed. W.N. Sainsbury. Covers the whole period 1574-1660. 1860. T. 1, № 1574-1660.

30. Bennet C.E. Settlement of Florida. Geinesville: University of Florida, 1968. 253 p.

31. Ashrafyan K.E., Koroleva N.E., Pospelova N.V., Achaeva M.S. Interrupted Game of England and French Huguenots on the Chessboard // Utopia y Praxis Latinoamericana. 2020. Vol. 25, № extra 10. P. 242-252.

\begin{tabular}{l|l}
\hline \multicolumn{1}{c|}{ Information about the author(-s): } & \multicolumn{1}{|c}{ Информация об авторе(-ах): } \\
\hline $\begin{array}{l}\text { Ashrafyan Konstantin Eduardovich, postgraduate } \\
\text { student of Archaeology, History of Ancient World } \\
\text { and History of the Middle Ages Department; Moscow }\end{array}$ & $\begin{array}{l}\text { Ашрафьян Константин Эдуардович, аспирант } \\
\text { кафедры археологии, истории древнего мира } \\
\text { и средних веков; Московский государственный } \\
\text { E-mail: kea6465@gmail.com. }\end{array}$ \\
$\begin{array}{l}\text { областной университет (г. Москва, Российская } \\
\text { Федерация). Е-таil: кеа6465@gmail.сот. }\end{array}$ \\
\hline
\end{tabular}

\section{Для цитирования:}

Ashrafyan K.E. "The Silver Age of Piracy»: French pirates in the Atlantic in the first third of the XVI century // Самарский научный вестник. 2020. T. 9, № 4. С. 232-239. DOI: 10.17816/snv202094204. 